\title{
Masalah dan Solusi Alternatif Pembelajaran Perancangan Elemen Mesin
}

\author{
Edi Septe $^{1^{*}}$ dan Nizwardi Jalinus ${ }^{2}$ \\ ${ }^{1}$ Fakultas Teknologi Industri Universitas Bung Hatta \\ ${ }^{2}$ Fakultas Teknik Universitas Negeri Padang \\ *corresponding author e-mail: edisepte019@gmail.com
}

\begin{abstract}
Abstrak- Kajian ini bertujuan menemukenali permasalahan dan solusi alternatif dalam pembelajaran Perancangan Elemen Mesin. Metodologi kajian dilakukan melalui penelusuran jurnal dalam lingkup pembelajaran machine design dari berbagai artikel ilmiah yang terbit secara online. Hasil kajian memperlihatkan masalah utama dalam pembelajaran Perancangan Elemen Mesin adalah: pembelajaran masih menerapkan metode tradisional, materi kuliah sudah tidak relevan dengan kebutuhan di lapangan, mahasiswa tidak memiliki pengetahuan dan pengalaman awal yang memadai, dosen kurang pengalaman membimbing mahasiswa melaksanakan praktek, kemampuan bahasa Inggris mahasiswa rendah, kurangnya paparan praktis mahasiswa, dan belum ada kerangka yang divalidasi untuk merancang pengembangan instruksional desain pembelajaran. Selanjutnya solusi alternatif yang ditawarkan adalah: membuat mahasiswa belajar aktif, materi kuliah diarahkan merancang sistem yang kompleks melalui program rekayasa proyek, mengembangkan model pembelajaran 'eksperimen bersama' yang membahas masalah lapangan.
\end{abstract}

Kata Kunci : perancangan elemen mesin, pembelajaran tradisional, pembelajaran elemen mesin, teknik hands-on, laboratorium virtual

\begin{abstract}
The purpose of this study is to identify problems and alternative solutions in design of machine elements learning. This literature review is conducted through searching journal within the scope of machine design learning in media online. The results of the study shown the main problems in design of machine elements learning are: the learning still apply the traditional method, the subject materials is not relevant to the field needs, the students do not have sufficient initial knowledge and experience, the lecturers lack experience guiding students to practice, lack of student English skills, the lack of practical exposure of students, and no validated framework for designing instructional development of instructional design. Furthermore the alternative solutions offered are: make students learn actively, the course material is directed to design complex system through project engineering program, develop the model of joint experiment study which discuss field problem.
\end{abstract}

Keywords : machine design, traditional learning, machine element learning, hands-on technique, virtual laboratory.

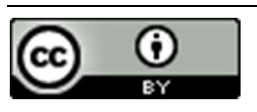

Sejak tahun tujuh puluhan, The Accreditation Board for Engineering and Technology (ABET) telah meningkatkan persyaratan desain teknik. Sebagai tindak lanjut dari hal tersebut, banyak perguruan tinggi dan universitas memasukkan mata kuliah proyek lapangan dalam kurikulum teknik dan mengembangkan mata kuliah desain atau perancangan sebagai upaya mempersiapkan lulusannya agar memiliki kemampuan dalam menangani masalah teknik praktis [1]. Hal tersebut terus berkembang sejalan dengan tuntutan kebutuhan industri terhadap sarjana teknik mesin yang memiliki kemampuan dalam merancang mesin [2], serta memiliki pengetahuan teoritis dan praktis [3].

Dengan demikian Jurusan Teknik Mesin menghadapi tantangan untuk mendidik mahasiswa agar menghasilkan lulusan dengan pengetahuan yang seimbang antara ilmu teknik dan desain mekanik. Tantangannya adalah perbedaan antara pengajaran berpikir analitis yang diperlukan untuk 
mata kuliah teknik, dan pemikiran desain untuk program desain berbasis proyek dan bagaimana menjembatani kesenjangan pendidikan antara pemikiran analitis dan desain atau pemikiran terintegrasi [4].

Pada Jurusan Teknik Mesin, mata kuliah yang menjadi dasar dalam peningkatan kompetensi mahasiswa dalam perancangan sistem mekanik adalah Mata Kuliah Perancangan Elemen Mesin. Oleh karena itu mata kuliah tersebut menjadi mata kuliah dasar teknik mesin yang sangat penting dan wajib dipelajari oleh semua mahasiswa [5],[6] dan [7]. Selain itu, penguasaan perancangan elemen mesin sangat penting bagi mahasiswa untuk mengikuti mata kuliah Jurusan Teknik Mesin lainnya [8].

Perancangan mesin meliputi perancangan perangkat dan sistem mekanis, oleh karena itu Sarjana Teknik Mesin harus kompeten dalam merancang elemen mesin yang merupakan bagian dari suatu mesin. Mata kuliah Perancangan Elemen Mesin berkaitan dengan berbagai gerak, yang mengemulasi karakteristik gerak yang terdapat pada berbagai jenis mesin [6]. Oleh karena itu mata kuliah ini berkaitan dengan berbagai topik, seperti : prinsip kekuatan material, desain sifat material, tegangan kombinasi, desain untuk berbagai jenis pembebanan, analisis dan perancangan kolom dan balok, serta elemen mesin utama, seperti: transmisi sabuk, rantai, roda gigi, poros, pasak, kopling, paking dan bantalan [9] dan [10].

Dalam konteks modern, memahami perancangan elemen mesin saja tidak cukup, mahasiswa dituntut untuk mampu menggunakan alat analisis imperatif dengan teknik terkini yang digunakan di industri [11]. Insinyur memiliki seperangkat alat canggih yang dapat digunakan untuk merancang sistem teknis yang kuat dan handal, namun peralatan tersebut jarang digunakan dalam desain di dunia pendidikan [12]. Mahasiswa juga diharapkan memiliki kemampuan mengintegrasikan berbagai komponen dan perangkat permesinan menjadi suatu sistem yang terkoordinasi dan kuat, yang melibatkan pengambilan beberapa keputusan. Selain itu mahasiswa juga diharapkan memahami dan memiliki kemampuan untuk mengevaluasi dampak desain teknik di masyarakat [10]. Menurut [7], untuk dapat bersaing di pasar global, industri memerlukan Sarjana Teknik Mesin yang memiliki keterampilan seperti pengetahuan multi disiplin, kemampuan komunikasi yang baik, dan rasa ingin tahu.

Dengan demikian dapat dinyatakan bahwa kemampuan Perancangan Elemen Mesin merupakan kompetensi yang dibutuhkan mahasiswa dalam pendidikan teknik. Akan tetapi, bagaimana kemampuan perancangan mereka saat lulus?, jenis keahlian perancangan apa yang dimiliki mahasiswa ?, seberapa jauh perbedaan kemampuan antara mahasiswa dan insinyur sebagai perancang ahli ? [13] dan bagaimana seorang mahasiswa teknik memahami apa artinya merancang [14], serta bagaimana meningkatkan kualitas pembelajarannya [15].

Dari uraian diatas terlihat bahwa mata kuliah Perancangan Elemen Mesin merupakan nafas dari kurikulum Jurusan Teknik Mesin, karena merupakan dasar bagi mata kuliah lain dan luaran pembelajarannya menjadi harapan bagi industri. Akan tetapi sejauh mana harapan tersebut dapat terpenuhi?. Pada bagian selanjutnya akan dijabarkan berbagai permasalahan yang terdapat dalam pembelajaran Perancangan Elemen Mesin dan solusi alternatif yang telah dilakukan pada berbagai perguruan tinggi.

Tujuan dari penulisan artikel ini adalah untuk menemukenali berbagai permasalahan yang terdapat dalam mata kuliah Perancangan Elemen Mesin dan solusi alternatif yang telah dilakukan, sehingga dapat dijadikan sebagai pedoman dalam pengembangan model pembelajaran mata kuliah Perancangan Elemen Mesin selanjutnya.

\section{Studi PUSTAKa}

Perancangan secara luas dianggap sebagai hal yang membedakan bidang teknik dengan bidang ilmu lain dan pendidikan teknik harus meluluskan insinyur yang dapat merancang solusi efektif untuk memenuhi kebutuhan sosial. Akan tetapi masih banyak pimpinan jurusan bidang teknik tidak mau mengenali kompleksitas dan sumber daya yang diminta untuk mendukung pendidikan perancangan yang baik [16].

Sampai saat ini, masih banyak dosen yang melaksanakan perkuliahan dengan metode ceramah tradisional [17], [18] dan [19], mengikuti pendekatan deduktif, berupa pembelajaran yang berpusat pada dosen yang menyampaikan dan menjelaskan konsep dari topik yang dibahas. Dosen memasukkan lebih banyak materi kuliah dan latihan dalam pembelajaran di kelas dengan waktu yang terbatas [18], kemudian mengharapkan mahasiswa menyelesaikan tugas untuk mempraktekkan konsep tersebut [20]. Namun hampir semua mahasiswa menggunakan buku petunjuk saat mengerjakan tugas [21]. 
Hal serupa dinyatakan oleh [22], dimana metode pengajaran merupakan penyampaian pengetahuan satu arah. Dosen memberikan pelajaran dengan interpretasi lisan atau mengulangi apa yang ada dibuku dan mahasiswa menyerap pengetahuan dengan mendengarkan ceramah, mencatat dan membaca sebelum atau sesudah kuliah.

Sejalan dengan itu pembelajaran perancangan elemen mesin juga terhambat oleh kurangnya pengalaman mahasiswa [23] karena mahasiswa baru tidak memiliki latar belakang teknik yang baik dan dengan latar belakang yang berbeda, sehingga terjadi kekosongan terkait dengan beragamnya gaya belajar mahasiswa [24]. Ketidakmampuan dosen memotivasi mahasiswa untuk mempelajari topik yang terkadang tidak jelas juga menjadi hambatan dalam pembelajaran. Mahasiswa sering tidak mempertimbangkan ambiguitas yang muncul dalam sifat iteratif rancangan, penuh dengan keputusan, dan konseptualisasi.

Selain itu materi kuliah yang dibahas di kelas sudah tidak relevan dengan kebutuhan analisis di lapangan [25]. Mahasiswa juga tidak mendapatkan praktek pada tahun awal kuliah dan dosen kurang pengalaman untuk membimbing mahasiswa melaksanakan praktek [26]. Ditambah lagi penilaian kemampuan mahasiswa dalam merancang diperumit oleh penilaian tradisional, sehingga menyisakan sedikit ruang untuk keputusan perancangan [23].

Persoalan lain yang terjadi dalam pembelajaran perancangan elemen mesin adalah mahasiswa tidak memiliki keterampilan bahasa Ingris yang baik, sehingga mengalami kendala dalam belajar menggunakan buku berbahasa Inggris [27]. Sedangkan [28] mengungkapkan bahwa metode pedagogi visual dan paparan praktis sangat penting dalam menangani subjek teknik untuk pemahaman dan pembelajaran konseptual, namun tidak tersedianya peralatan di laboratorium dan kurangnya paparan praktis akan menurunkan pemahaman mahasiswa tentang konsep dasar rekayasa.

Disisi lain [29] berpendapat bahwa permasalahan dalam pembelajaran Perancangan Elemen Mesin disebabkan belum adanya kerangka yang divalidasi untuk merancang program pengembangan instruksional dalam melakukan perubahan model tradisional desain pendidikan teknik. Padahal para dosen diharapkan memperkuat cakupan fundamental tentang desain dan operasi rekayasa 'dunia nyata', serta menawarkan instruksi yang lebih banyak dan lebih baik dalam keterampilan komunikasi lisan dan tertulis, serta kerja sama tim [30]. Akibatnya ada kekhawatiran tentang retensi mahasiswa yang buruk dalam bidang teknik yang dikombinasikan dengan dunia nyata [31]. Selain itu penilaian kinerja sebagai metode evaluasi keterampilan belum dibuat dalam bentuk rubrik yang mengidentifikasi tingkat kinerja yang ditunjukkan mahasiswa [32].

Terdapat beberapa permasalahan dalam pembelajaran perancangan elemen mesin [33]. Pertama, mahasiswa pada umumnya kurang berpengalaman dengan peralatan dan mesin. Kedua,mahasiswa tidak siap untuk menerapkan pemahaman teoritis terhadap masalah nyata. Ketiga, mata kuliah ini pada dasarnya merangkum sebagian besar pengetahuan teknik mesin yang ada sebelum Perang Dunia II, sehingga mengajarkan dasar-dasar komponen ini tidak benar-benar melengkapi mahasiswa dengan intuisi mekanis sebagaimana yang diperoleh para insinyur seratus tahun lalu melalui program mentoring ekstensif.

Dari masalah yang terungkap dalam pembelajaran Perancangan Elemen Mesin, beberapa peneliti menyampaikan solusi alternatif terhadap masalah tersebut. Pembelajaran bidang perancangan harus membuat mahasiswa belajar aktif dan bergeser dari generik ke spesialis dan dari abstrak ke mode kerja konkret, serta menjadikan studio yang komprehensif dan kolaboratif sebagai platform, di mana pembelajaran berbasis sosial, interdisipliner dan inkuiri dikembangkan sesuai tema, proses dan metode perancangan yang dipilih [34].

Materi kuliah Perancangan Elemen Mesin sebaiknya diarahkan untuk merancang dam membangun sistem yang kompleks, serta menekankan tema pengembangan produk [35]. Pembelajaran perancangan dilakukan melalui program rekayasa proyek yang memenuhi semua topik dan tujuan pembelajaran [23] dan memberi pengalaman praktis serta dampak terhadap pengembangan keterampilan interpersonal, komunikasi dan peningkatan kepercayaan diri dan motivasi belajar mahasiswa [36].

Metodologi instruksional untuk memenuhi kebutuhan industri dengan mengidentifikasi metode studi kasus sebagai teknik instruksional yang paling sesuai dalam pembelajaran perancangan elemen mesin [37]. Pembelajaran dilakukan dengan menciptakan pendekatan topdown yang terintegrasi untuk mengajarkan konten teknik melalui pelaksanaan proyek desain teknik yang mengintegrasikan keterampilan, teknik, dan peralatan yang relevan. Hal tersebut akan 
membantu pemahaman konsep umum mekanika dan meningkatkan keterampilan desain teknik [38].

Isu-isu kebijakan publik dapat diperkenalkan sebagai bagian integral dan logis dari pembelajaran perancangan melalui diskusi kelas, studi kasus, pekerjaan rumah, kuis dan ujian di kelas, serta proyek desain mini dalam beberapa minggu dan proyek desain lapangan [39]. Kegiatan ini didukung dengan membuat serangkaian tugas digital yang dapat memberikan penilaian terhadap dampak pembelajaran mahasiswa [40]. Model konseptual ALOE (Assessment of Learning Outcomes in Engineering) dapat digunakan untuk menggambarkan hasil belajar dan penilaian yang tepat dan untuk mencapai keselarasan antara dua komponen dari proses pendidikan [41].

Kegiatan mahasiswa dalam proyek perancangan dapat dilakukan di Laboratorium Desain dan Manufaktur. Kegiatan ini mengikuti metodologi perancangan yang mencakup tinjauan desain dan dokumentasi yang sesuai dengan sistem yang dirancang, diproduksi, dirakit dan diuji oleh mahasiswa.( Cohen dan Katz, 2015). Pembelajaran di laboratorium ini dapat mencapai dua tujuan, yaitu: menghasilkan informasi bagi mahasiswa tentang sifat teknik dan meningkatkan retensi mahasiswa di bidang teknik [42]. Sebagai pengembangan pembelajaran di laboratorium dapat dilakukan dengan modul laboratorium virtual atau simulasi laboratorium yang sangat interaktif, termasuk klip video dan menggunakan aplikasi spreadsheet [43].

Pembelajaran Perancangan Elemen Mesin dapat dilakukan dengan pendekatan pedagogik yang dilakukan melalui pengembangan teknik hands-on berbasis tim [44]. Memberikan pengalaman praktis hands-on kepada mahasiswa dalam perancangan, fabrikasi, dan pengujian sistem mekanis akan memberikan pemahaman mendalam tentang prinsip-prinsip kunci yang mengatur pemilihan dan integrasi komponen mesin ke dalam sistem kerja yang kuat dan efisien [45] dan [46]. Membuat konstruksi fisik dari sebuah model selama tugas perancangan dapat membantu mahasiswa menghasilkan dan mengevaluasi ideide mereka, serta membantu mahasiswa menemukan perbedaan antara perilaku nyata dan model konseptual. Selain itu membangun model juga meningkatkan pemikiran kreatif dan membantu mahasiswa menjadi lebih sadar akan strategi perancangan metakognitif [47] dan[6].

Memanfaatkan perangkat lunak dan perangkat keras open-source, dan platform pendukung publik sebagai media yang sempurna bagi mahasiswa teknik untuk mempelajari konsep teknik dan memperoleh keterampilan dalam konteks perancangan yang menyenangkan dan akhirnya mahasiswa belajar bagaimana berinovasi dan menemukan mesin [48]. Penggunaan video game dapat menjembatani hampir semua instruksi kelas, latihan, tugas, dan proyek kelas. Tujuannya adalah untuk memanfaatkan aspek-aspek permainan video yang begitu menarik bagi mahasiswa [49] dan [50], serta memberi peluang kepada mahasiswa untuk malaksanakan pembelajaran sains melalui perancangan teknik dengan menyeimbangkan manfaat desain dan pemasaran [51].

Menurut [52] pembelajaran Perancangan Elemen Mesin dilakukan dengan merubah pendekatan pedagogis melalui tiga langkah mendasar, yaitu: kontekstualisasi, strukturisasi dan rekontekstualisasi. Dalam proses belajar diterapkan model pembelajaran berbasis masalah (project based learning) dan proyek (project led education). Meskipun konsekuensi dari pendekatan ini harus mengurangi jumlah topik yang dibahas, akan tetapi pemahaman mahasiswa akan lebih mendalam dan mahasiswa juga dapat meningkatkan keterampilan mereka dalam pemecahan masalah. Untuk itu perlu dikembangkan bahan ajar yang mengandung semua informasi penting yang biasanya diterapkan dilapangan, seperti berkas tender, model 3D interaktif, gambar, proses (pengelasan, pemesinan, perakitan) untuk dipelajari mahasiswa [2]. Kegiatan ini dilengkapi dengan pandangan [53] yang menyatakan bahwa refleksi telah diidentifikasi sebagai faktor kunci yang mendukung pembelajaran dalam meningkatkan manajemen pengetahuan dalam pendidikan desain oleh mahasiswa dan pengembangan profesional berkelanjutan oleh dosen.

Penting untuk mengembangkan praktik reflektif sebagai keterampilan dasar untuk kolaborasi [54]. Untuk itu penerapan Think-Maps sebagai pendekatan alternatif dan pelengkap merancang pengajaran dan pembelajaran dalam pendidikan desain [55]. Sedangkan menurut [56], menerjemahkan hasil penelitian ke dalam praktik mengajar memberikan dampak positif terhadap pengajaran dalam pendidikan perancangan teknik. Keterampilan pribadi, profesi dan interpersonal dikembangkan melalui pembelajaran berbasis inkuiri, dengan cara mengidentifikasi masalah dan terlibat dalam analisis yang membutuhkan estimasi dan ketidakpastian. Sedangkan keterampilan kelompok dan komunikasi dikembangkan melalui diskusi teman sebaya dan presentasi penelitian dalam bentuk poster dan seminar [57]. 
Pembangunan prototipe merupakan aspek penting dari proses perancangan produk untuk mempelajari faktor-faktor apa yang penting dalam pembuatan prototipe hasil perancangan [58]. Pembelajaran dilakukan melalui pengembangan Sistem Level Diagram (SLD) dinamis, di mana mahasiswa merubah sistem dan kebutuhan ke diagram blok dua dimensi. SLD dibangun dengan mengatur setiap komponen dan antarmuka menggunakan metodologi flowchart, di mana jumlah komponen didasarkan pada masalah desain sementara antarmuka didefinisikan berdasarkan aspek fisik seperti fisika, fasilitas manufaktur lokal dan batas kondisi struktur yang tersedia [59] dan [60].

Mahasiswa Teknik Mesin digabung dengan mahasiswa perdagangan dengan misi mengembangkan produk baru dan pemasaran [61]. Model Search, Structuring and Confrontation (SSC) dapat dikembangkan untuk memberikan dinamika dalam kegiatan flipping dan mengembangkan semangat tim di kelas [62]. Hal tersebut menjadi bagian dari pembelajaran pengambilan keputusan dalam proses desain rekayasa yang dilakukan melalui identifikasi dan klarifikasi masalah serta diskusi penyelesaian masalah dan merencanakan proses perancangan [63].

\section{Metode}

Setiap gambar diberi nomor urut 1,2,3 dan seterusnya tanpa mengikutsertakan nomor bagian/bab dari artikel, seperti pada Gambar 1. Suatu rangkaian gambar-gambar yang saling berhubungan dapat diberi nomor urut gabungan angka dan abjad seperti 2a, $2 \mathrm{~b}$ dan seterusnya.

Kajian literatur ini dilakukan melalui beberapa tahapan, yang diawali dengan menggali informasi melalui penelusuran dan pengumpulan jurnal dalam lingkup pembelajaran Perancangan Elemen Mesin atau Machine Design menggunakan jaringan internet. Sumber informasi yang digunakan antara lain: google scholar, springer, Elsevier dan sage. Kunci pencarian yang digunakan adalah: machine design, machine design learning, teaching and learning of machine design, mechanical design, machine elements.

Selanjutnya metode yang diterapkan diperlihatkan dalam bentuk diagram seperti diperlihatkan pada Gambar 1.

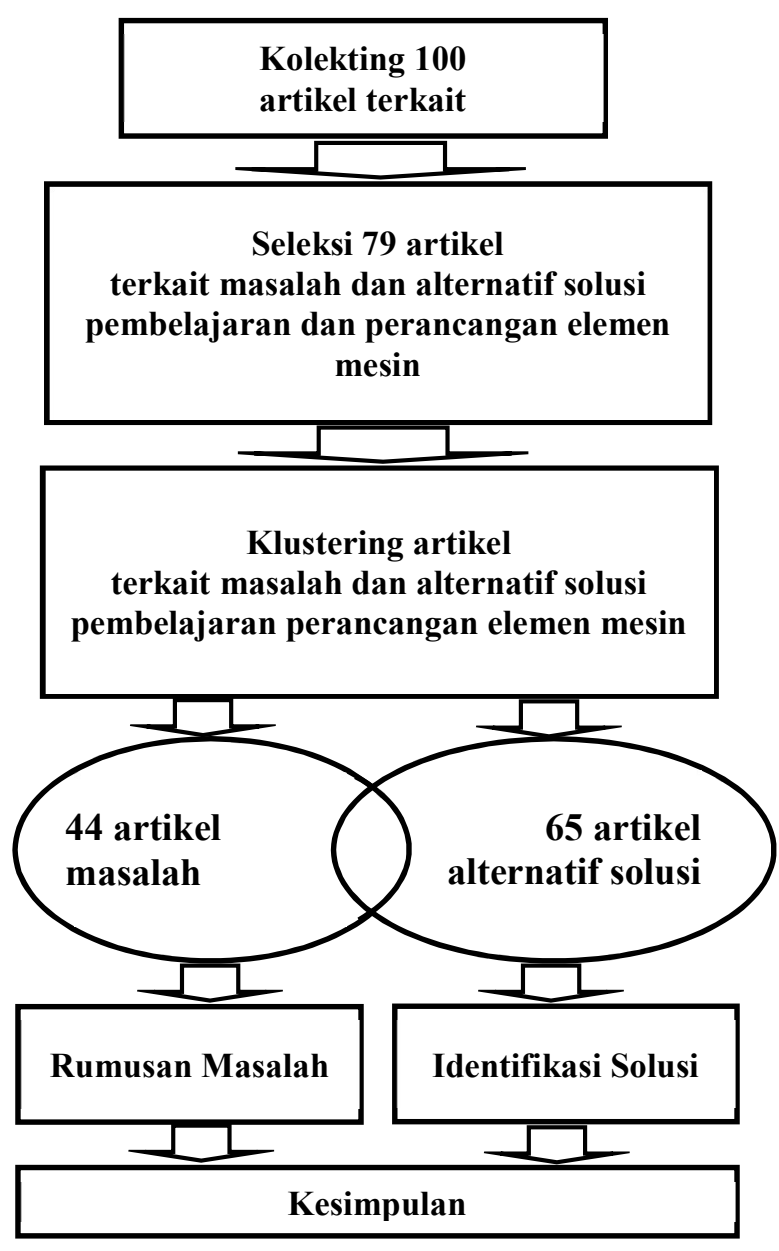

Gambar 1. Diagram metode kajian masalah dan alternatif solusi pembelajaran Perancangan Elemen Mesin.

\section{HASIL DAN PEMBAHASAN}

Berbagai permasalahan telah ditemukenali dalam pembelajaran perancangan elemen mesin. Dari 44 artikel yang mengungkapkan masalah sebagian besar atau $55 \%$ menyatakan masalah yang terjadi dalam pembelajaran perancangan elemen mesin adalah metode pembelajaran. Selanjutnya $14 \%$ berkaitan dengan kurikulum, keterbatasan waktu pembelajaran dan sumberdaya yang tersedia. Sedangkan masing-masing $9 \%$ menyatakan masalah diinisiasi oleh sistem penerimaan mahasiswa baru dan pengalaman praktis awal yang kurang memadai. Materi belajar dan metode evaluasi juga menjadi masalah dalam pelaksanaan pembelajaran untuk mencapai tujuan pembelajaran. Selain itu penguasaan bahasa Inggris juga diungkapkan sebagai masalah dalam pembelajaran perancangan elemen mesin, sebagaimana diperlihatkan pada Gambar 2.

Dari tujuh kategori masalah yang diungkap, terlihat bahwa pelaksanaan pembelajaran tradisional menjadi hal yang penting untuk diatasi. 


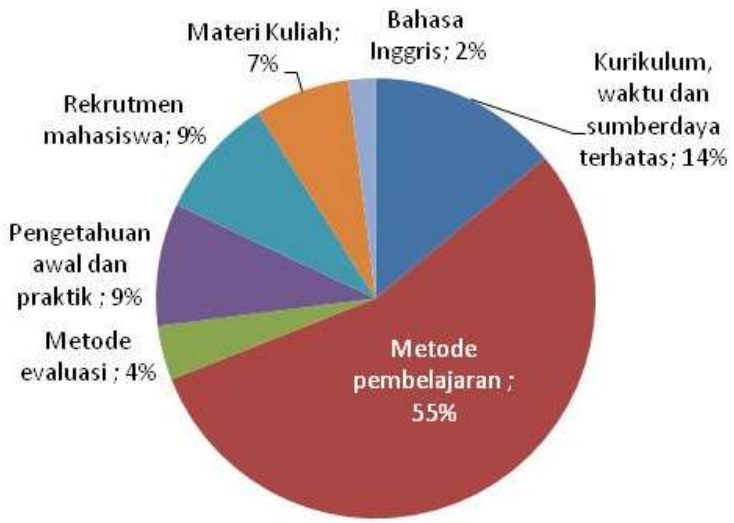

Gambar 2. Persentase masalah dalam pembelajaran perancangan elemen mesin.

Dalam pembelajaran tersebut mahasiswa lebih banyak mengingat segala sesuatu yang dipelajari, tanpa memahami maksudnya [9]. Sebagian besar waktu di kelas dihabiskan dengan dosen mengajar dan mahasiswa menonton, mendengarkan, dan menulis. Mahasiswa lebih banyak bekerja secara individu dan kerja sama sangat rendah [64]. Hal tersebut membuat sebagian besar mahasiswa kurang inisiatif dan tidak memiliki keberanian untuk mengungkapkan gagasan mereka sehingga mempengaruhi efektifitas pembelajaran.

Akibatnya mahasiswa menghadapi kesulitan memahami topik bahasan dalam perkuliahan, karena karakter geometris dan morfologis subjek yang kuat (seperti bentuk, ukuran dll.) dan pengembangan abstrak yang simultan atau entitas intelektual yang dirasakan (seperti tekanan, tegangan, kerusakan) sulit dibayangkan melalui teori [65]. Dengan demikian mahasiswa gagal memahami konsep dasar [66].

Kalaupun dilaksanakan dengan baik, pembelajaran dengan ceramah di kelas dan tugas pekerjaan rumah hanya memperkuat konsep analisis dengan memecahkan masalah melalui penyisipan parameter yang diberikan ke dalam persamaan yang baru dipelajari. Meskipun mahasiswa cukup paham teori, tetapi mereka berjuang keras saat diberi masalah dengan solusi ambigu [67]. Padahal mata kuliah perancangan elemen mesin mencakup banyak materi dan sebagian besar adalah pengetahuan teoritis yang kompleks.

Banyaknya masalah yang diajarkan dan tingkat kerumitannya yang semakin meningkat dalam batas waktu pembelajaran yang terbatas sebagaimana ditetapkan kurikulum, membuat lebih sedikit waktu untuk mengajar [68]. Upaya mengatasi dengan mode pembelajaran yang menggabungkan buku teks dengan powerpoint menyebabkan mahasiswa kehilangan minat dalam kuliah, sehingga pengetahuan menjadi sulit didapat. Akibatnya perancangan elemen mesin dianggap oleh mahasiswa sebagai mata kuliah yang sulit [69].

Disisi lain, pembelajaran tradisional yang diterapkan dosen membuat mahasiswa yang memiliki kemampuan belajar relatif tinggi merasa tidak puas karena potensi yang mereka miliki tidak terpenuhi. Sebaliknya mahasiswa yang memiliki kemampuan belajar yang relatif rendah akan kehilangan minat belajar, karena merasa kurang termotivasi [70].

Berdasarkan kajian 65 literatur, terdapat setidaknya lima komponen pengembangan yang dilakukan sebagai alternatif solusi terhadap masalah yang terjadi pada pembelajaran perancangan elemen mesin. Kelima alternatif solusi tersebut adalah: pengembangan model pembelajaran, pengembangan metode pembelajaran, pengembangan metode penilaian, pengembangan kurikulum dan materi kuliah, serta peningkatan kapasitas dosen. Persentase peneliti yang mengusulkan kelima alternatif solusi tersebut diperlihatkan pada Gambar 3.

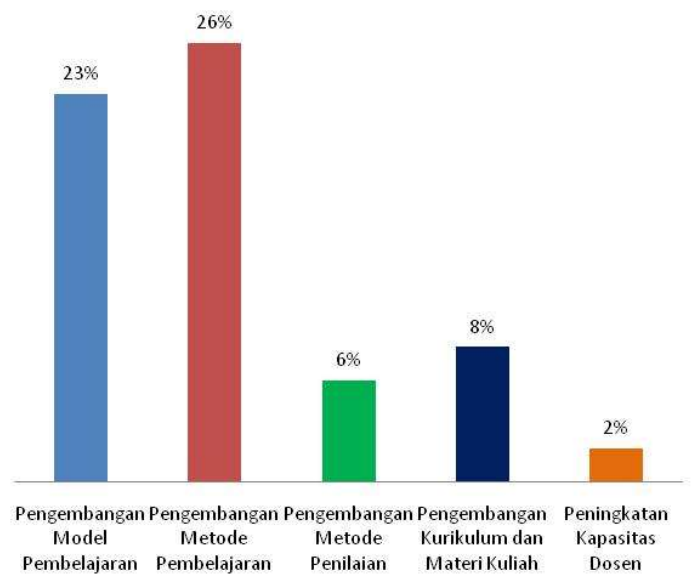

Gambar 3. Persentase usulan alternatif solusi pembelajaran perancangan elemen mesin.

Mengembangkan model pembelajaran problem dan projek based learning yang memiliki orientasi beragam masalah lapangan, merupakan model yang direkomendasikan, karena memiliki kekuatan utama pada kapasitas melakukan sintesis kreatif sehingga dapat meningkatkan kualitas hasil kerja mahasiswa [71]. Pendekatan yang dilakukan adalah dengan memperluas pembelajaran dan pengalaman mahasiswa dengan memberikan 
kesempatan untuk mengarahkan pembelajaran mereka sendiri, menciptakan komunitas praktek, menggabungkan penilaian sinergis, dan menyediakan evaluasi mendalam untuk mendemonstrasikan pengetahuannya [72].

Pembelajaran eksperimen di laboratorium juga dapat dilakukan untuk memberikan mahasiswa kesempatan menerapkan pembelajaran kelas ke lingkungan yang nyata, dimana prosesnya dapat diakses dari tempat lain melalui jaringan internet [64]. Lebih lanjut penerapan strategi training within industry dapat meningkatkan kinerja mahasiswa dalam melaksanakan praktikum [73].

Pekerjaan insinyur adalah sebagai pemecah masalah, yang hampir selalu dilakukan dalam tim atau dalam kerja sama informal dengan orang lain [74], oleh karena itu penerapan proyek perancangan berbasis tim dengan pendekatan pembelajaran berbasis masalah tepat untuk dikembangkan. Dalam hal ini komunikasi yang jelas merupakan keterampilan yang paling penting dan keterampilan didaktik diperkuat melalui role playing untuk meningkatkan motivasi dan antusiasme belajar, serta meningkatkan pemahaman kuantitatif mahasiswa [75].

\section{KESIMPULAN}

Mata kuliah Perancangan Elemen Mesin merupakan mata kuliah penting dalam kurikulum Jurusan Teknik Mesin, sebagai media penyeimbang antara ilmu teknik dan desain mekanik. Kompetensi perancangan elemen mesin yang dimiliki mahasiswa sangat dibutuhkan oleh industri untuk menyelesaikan berbagai masalah yang terdapat di lapangan.

Dalam pembelajaran Perancangan Elemen Mesin ditemukenali berbagai permasalahan untuk mencapai tujuan pembelajaran sebagaimana yang direncanakan. Hasil telaah literatur yang dilakukan memperlihatkan tujuh kategori masalah yaitu metode pembelajaran; kurikulum, keterbatasan waktu pembelajaran dan sumberdaya yang tersedia; sistem penerimaan mahasiswa baru; pengalaman praktis awal yang kurang memadai; materi belajar; metode evaluasi; serta penguasaan bahasa Inggris.

Metode pembelajaran menjadi masalah paling krusial yang terjadi, terutama pembelajaran yang masih dilakukan dengan menerapkan metode pembelajaran tradisional. Dengan topik bahasan yang sangat kompleks, metode ini tidak efektif untuk mendidik mahasiswa dan membantu mereka memahami materi dari topik bahasan secara tuntas [76] dan [77].
Perkembangan teknologi yang cepat, latar belakang pengalaman mahasiswa yang berbeda, dan gradasi pekerjaan yang terbuka mendorong perkembangan baru dalam teknologi dan tuntutan perubahan mahasiswa [78]. Dalam situasi ini ada kebutuhan untuk mengembangkan metode pembelajaran yang lebih efektif dan menarik [8] dan [68].

Membuat mahasiswa belajar aktif dan bergeser dari generik ke spesialis dan dari abstrak ke mode kerja konkret dengan materi kuliah yang diarahkan untuk merancang dam membangun sistem yang kompleks, serta menekankan tema pengembangan produk melalui program rekayasa proyek, merupakan alternatif solusi yang dapat diterapkan.

Mengembangkan pembelajaran 'eksperimen bersama' yang membahas beragam masalah lapangan yang memiliki kekuatan utama pada kapasitas melakukan sintesis kreatif, serta menggerakkan mahasiswa dalam proyek perancangan di laboratorium dengan modul laboratorium virtual atau simulasi laboratorium interaktif juga menjadi metode pembelajaran baru.

Selanjutnya pembelajaran perancangan mesin juga dapat dilakukan dengan pendekatan pedagogik melalui pengembangan teknik hands-on berbasis tim dalam perancangan, fabrikasi, dan pengujian sistem mekanis [79]. Metode ini diharapkan dapat memberikan pemahaman mendalam tentang prinsip-prinsip kunci dalam pemilihan dan integrasi komponen mesin ke dalam sistem kerja yang kuat dan efisien. Sehingga mahasiswa dapat mengembangkan produk baru hasil rancangan mereka.

\section{DAFTAR PUSTAKa}

[1] Ambrose. S.A and Amon. C.H, 1997, Systematic Design of a First-Year Mechanical Engineering Course at Carnegie Mellon University, Journal of Engineering Education, pp 173-181.

[2] Jiang. H and Yen. C.C, 2013, Design Thinking in Conceptual Design Processes: A Comparison Between Industrial and Engineering Design Students, Advances in Industrial Design Engineering, http://dx.doi.org/10.5772/52460

[3] Jirásko. J, Raab. Z dan Klepácek. J, 2015, Elearning study materials focused on projects from industry, Procedia - Social and Behavioral Sciences 176 ( 2015 ) 722-729

[4] Katz. R, 2015, Integrating Analysis and Design in Mechanical Engineering Education, Procedia Conference Innovative Product Creation, 36 ( 2015 ) 23-28 
[5] Turner. D and Nagurka. M, 2014, Helicopters as a Theme in a Machine Design Course, Proceedings of the conference, $121^{\text {st }}$ ASEE Annual Conference \& Exposition, Atlanta, 2014, Paper ID \#10409. American Society for Engineering Education, 2014

[6] Mikhail. $\mathrm{M}$ and Engle. C.D, 2017, Enhancing Machine Design Course with an Integrated Vending Machine System, ASEE Paper ID \#17760, American Society for Engineering Education, 2017

[7] Li. H, Öchsner. A and Hall. W, 2017, Application of experiential learning to improve student engagement and experience in a mechanical engineering course, European Journal Of Engineering Education, 2017, Taylor and Francis

[8] Tian. F, 2014, Improve Teaching Quality of Machine Design Course by Comprehensive Application of Multiple Meth, International Conference on Education Reform and Modern Management (ERMM 2014)

[9] Stalford. H.L, 2014, Hands-On Method for Teaching Design of Mechanical Components Course, Proceedings of the conference, $121^{\text {st }}$ ASEE Annual Conference \& Exposition, Atlanta, 2014, American Society for Engineering Education, 2014

[10] Sivaloganathan. S and Omar. F.K, 2016, Designing with Lessons from the Machine Design Course: A Capstone Experience, American Society for Engineering Education 123 ${ }^{\text {rd }}$ Annual Conference and Exposition Paper ID \#15609, American Society for Engineering Education

[11] Abumahaimed. M and Rencis. J.J, 2011, Mechanics of Materials, Machine Design, and Vibrations Finite Element Learning Modules for Undergraduate Courses, Proceedings Midwest Section Conference of the American Society for Engineering Education, Arkansas September 28-30, 2011.

[12] Rompelman. O and De Graaff. E, 2006, The engineering of engineering education: curriculum development from a designer's point of view, European Journal of Engineering Education, Vol. 31, No. 2, 2006, 215-226

[13] Atman. C.J, Adams. R.S, Cardella, M.E, Turns. J, Mosborg.S and Saleem. J, 2007, Engineering Design Processes: A Comparison of Students and Expert Practitioners, Journal of Engineering Education, pp 359-379

[14]Daly. S.R, Adams. R.S and Bodner. G.M, 2012, What Does it Mean to Design? A Qualitative Investigation of Design Professionals' Experiences, Journal of Engineering Education, 2012, Vol. 101, No. 2, pp. 187-219

[15] Monterrubio. L.E and Sirinterlikci. A, 2015, A Hands-on Approach in Teaching Machine Design, $122^{\text {nd }}$ ASEE Annual Conference \& Explotion, Seatle WA Paper ID \#11528, American Society for Engineering Education, 2015
[16] Dym. C.L, Agogino. A.M, Eris. E, Frey. D.D and Leifer. L.J, 2005, Engineering Design Thinking, Teaching, and Learning, Journal of Engineering Education, Vol 94, Issue 1, January 2005. P 103120

[17]Benedict. B.A, 2016, Studying Elements of SelfPaced Learning and Flipped Classroom to Enhance Course Design, Proceedings of International Conference on Engineering Education and Research, 21-24 Nov 2016, Western Sydney University, Parramatta Campus, Sydney, Australia

[18] Sun. L, Chen. H, and Pang. S, 2017, Students' Perception of Flipped Classroom Design in Engineering Courses, ASEE Southeast Section Conference, American Society for Engineering Education

[19]Long. J.M, Pereira. M, and Chandrasekaran. S, 2017, Implementation of Project-Oriented DesignBased Learning in a Second-Year Mechanical/Mechatronics Subject, Proceedings, AAEE2017 Conference Manly, Sydney, Australia

[20] Ahmed. A, Haque. M.M, Rahman. M.A and Rahman. A, 2016, Engineering Education in Bangladesh: Implementation of Online Delivery Approach, Proceedings of International Conference on Engineering Education and Research, 21-24 Nov 2016, Western Sydney University, Parramatta Campus, Sydney, Australia

[21] Alemayehu. F.M, Logan. M.M and Barhorst. A, 2015, Development of a comprehensive assessment technique to invigorate students' problem-solving skills and deter cheating, International Journal of Mechanical Engineering Education 2015, Vol. 43(4) 265-285

[22] Chang. T.C, Tsai. Y.F, dan Wu. F.G, 2015, Interaction Design of Digital Teaching Improves Teaching and Learning Effectiveness, M. Antona and C. Stephanidis (Eds.): UAHCI 2015, Part III, LNCS 9177, pp. 15-22, 2015.DOI: 10.1007/978-3319-20684-4_2, Springer International Publishing Switzerland

[23] Steuber. J.G, 2011, The Machine Component Design Manual Project and Other Tools for Teaching Mechanical Design, Proceedings of the Midwest Section Conference of the American Society for Engineering Education

[24] Wood. J, Campbell. M, Wood. K and Jensen. D, 2005, Enhancing the teaching of machine design by creating a basic hands-on environment with mechanical 'breadboards, International Journal of Mechanical Engineering Education 33/1 January 2005, SAGE Publications

[25] Goh. Y.M,, McMahon. C.A, and Booker. J D, 2009, Improved utility and application of probabilistic methods for reliable mechanical design, Proceedings of the Institution of Mechanical Engineers, Part O: Journal of Risk and Reliability, 
Vol. 223, pp 199-214, DOI: 10.1243/1748006XJRR244

[26] Benne and Male. S.A, 2016, An Australian study of possible selves perceived by undergraduate engineering students, European Journal of Engineering Education, 2016, DOI: 10.1080/03043797.2016.1208149

[27] Golenko.A, 2014, Zeszyty Naukowe Politechniki Śląskiej, Seria: Transport z. 83 Nr kol. 1904, 2014, Teaching Fundamentals of Machine Design In English

[28] Sharma. G.V.S.S and Dumpala. R, 2015, Teaching of mechanical engineering concepts through threedimensional geometric modeling, International Journal of Mechanical Engineering Education, 0(0) 1-11, SAGE Publisher, 2015..DOI: 10.1177/0306419015603013

[29]Felder. R.M, Brent. R and Prince. M.J, 2011, Engineering Instructional Development:Programs, Best Practices, and Recommendations, Journal of Engineering Education, 100(1), 89 -122 (2011)

[30]Felder. R.M, Woods. D.R, Stice. J.E and Rugarcia. A, 2000, The Future of Engineering Education : Teaching Methods That Work, Chemical Engineering Education, 34(1), 26-39 (2000)

[31] Freuler. R.J, Fentiman. A.W, Demel. J.T, Gustafson. R.J and Merrill. J.A, Developing and Implementing Hands-on Laboratory Exercises and Design Projects for First Year Engineering Students, Proceedings of the 2001 American Society for Engineering Education Annual Conference \& Exposition

[32] Asunda. P.A and Hill. R.B, 2007, Critical Features of Engineering Design in Technology Education, Journal of Industrial Teacher Education, Vol. 44 Np.1, pp 25-36

[33] Campbell. M.I and Schmidt. K.J, 2005, Incorporating Open-Ended Projects into a Machine Elements Course, Proceedings of the 2005 American Society for Engineering Education Annual Conference \& Exposition Copyright (C) 2005, American Society for Engineering Education

[34]Liem. A and Sigurjonsson. J.B, 2014, Positioning Industrial Design Education within Higher Education: How to face increasingly challenging market forces?, Uniped argang 37, 2/2014, side 4457

[35] Calabro. K.M, Kiger. K.T, Lawson. W and Zhang. G, 2008, New Directions in Freshman Engineering Design at the University of Maryland, 38th ASEE/IEEE Frontiers in Education Conference

[36] Dutson. A.J, Todd. R.H, Magleby. S.P and Sorensen. C.D, 1997, A Review of Literature on Teaching Engineering Design Through ProjectOriented Capstone Courses, Journal of Engineering Education, p 17-28
[37] Raju. P.K, Sankar. C.S, Halpin. G and Glennelle. H, 2000, An Innovative Teaching Method to Improve Engineering Design Education, ASEE Conference paper No. 1093, St. Louis, MO, 2000

[38] Covill. D, Katz. T and Morris. R, 2007, A Top Down Approach to Teaching Engineering Mechanics, International Symposium for Engineering Education, 2007, Dublin City University, Ireland

[39] Hyman. B, 2003, Public Policy and Engineering Design Education, International Journal of Engineering Education. Vol. 19, No. 1, 2003, pp. 110-117

[40] Canfield. S.L and Zuccaro. S.G, 2016, Digital homework for kinematics and dynamics of machinery, International Journal of Mechanical Engineering Education, 2016, Vol. 44(2) 165-182, DOI: $10.1177 / 0306419016641008$

[41] Soeiro. A and Falcão. R, 2013, Assessment of Student Learning Outcomes in Engineering Education and Impact in Teaching, International Conference on Engineering Education\& International Conference on Information Technology, 2013

[42] Hoit. M and Ohland. M, 1998, The Impact of a Discipline-Based Introduction to Engineering Course on Improving Retention, Journal of Engineering Education, American Society for Engineering Education, Vol.87 (1), January 1998, pp 79-85

[43] Anderson. E.E and Hashemi. J, 2006, Virtual Laboratories: Changing Engineering Education, Paper $9^{\text {th }}$ International Conference on Engineering Education July 23 - 28, 2006

[44] McLaren. A, 2008, Approaches to the Teaching of Design an Engineering Subject Centre guide, Higher Education Academy Engineering Subject Centre

[45]Farouki. R.T and Linke. B.S, 2016, Shigley Hauler-A competitive project illustrating basic machine design principles, International Journal of Mechanical Engineering Education 2016, Vol. 44(4) 284-301, SAGE Publisher, 2016.

[46] Serdar. T, 2015, Project based learning in Manufacturing Processes Course, American Society for Engineering Education

[47]Lemons. G, Carberry. A, Swan. C and Rogers. C, 2010, The Benefits of Model Building in Teaching Engineering Design, Design Studies Elsevier Ltd, 31 (2010) 288-309

[48] Purwar. A, 2016, Enabling Machine Design Innovation among Freshman Mechanical Engineering Students, $123^{\text {rd }}$ ASEE Annual Conference \& Explotion, Mew Orleasn LA Paper ID \#16469,American Society for Engineering Education, 2016 
[49] Coller. B.D and Scott. M.J, 2009, Effectiveness of Using a Video Game to Teach A Course in Mechanical Engineering, Computers \& Education 53 (2009) 900-912

[50] Galaup. M, Muller. N, Lelardeux. C.P, Panzoli. D, Jessel, J.P, Lagarrigue. P, 2017, Design of learning environments for Mechanical Engineering, Procedia Manufacturing 13 (2017) 1440-1446

[51] Purzer. S, Goldstein. M.H, Adams. R.S, Xie. C and Nourian. S, 2015, An exploratory study of informed engineering design behaviors associated with scientific explanations, International Journal of STEM Education (2015) 2:9

[52] Raucent. B, 2001, Introducing problem-based learning in a machine design curriculum: Result of an experiment, Journal of Engineering Design 12:4, 293-308

[53] Agouridas. V and Race. P, 2007, Enhancing Knowledge Management in Design Education Through Systematic Reflection Practice, Concurrent Engineering: Research and Applications Volume 15 Number 1 March 2007

[54] Prudhomme. G, Boujut. J.F.O and Brissaud. D, 2003, Toward Reflective Practice in Engineering Design Education, International Journal Engineering Education. Vol. 19, No. 2, pp. 328-337, 200

[55] Oxman. R, 2004, Think-Maps: Teaching Design Thinking In Design Education, Design Studies 25 (2004) 63-91

[56] Turns. J, Cardella. M, Atman. C.J, Martin. J, Newman. J and Adams. R.S, 2006, Tackling the Research-to-Teaching Challenge in Engineering Design Education: Making the Invisible Visible, International Journal of Engineering Education. Vol. 22, No. 3, pp. 598-608, 2006

[57] McLaren, A.J. and Jenkins, P, 2010, Mechanical Dissection in An Introductory Engineering Design Module, $6^{\text {th }}$ International CDIO Conference, 15-18 June 2010, Montréal, Canada

[58] Yang. M.C and Epstein. D.J, 2005, A study of Prototypes, Design Activity, and Design Outcome, Design Studies 26 (2005) 649-669

[59] Youssef. G and Arutyunov. V, 2013, An Approach to Integrate Systems Engineering into Senior Design, ASEE 123 Annual Conference and Exposition, New Orleans, LA, June 2016

[60] Williams. B and Figueiredo. J, 2014, From Academia to Start-up: A Case Study with Implications for Engineering Education, International Journal of Educational Psychology Vol 4, Issue 1, 2014

[61] Audet. J and Pegna. J, 2001, Engineering and Commerce Students Join Forces With a Corporate Sponsor, New Product Development Industry \& Higher Education, August 2001, p 257-267
[62] Aqqal. A, Elhannani. A, Haidine. A and Dahbi. A, 2017, Improving the Teaching of ICT Engineering Using Flipped Learning: A Personalized Model and A Case Study, Production, 27(spe), e20162274, 2017

[63] Meyer. H, 2018, Teachers' Thoughts on Student Decision Making During Engineering Design Lessons, Journal of Educaion Science, 2018, 8, 9

[64] Nagurka. M, Anton. F.R, Marklin. R, Jr, 2013, Using Remote Access for Sharing Experiences in A Machine Design Laboratory, The World Engineering Education Forum, Asociación Colombiana de Facultades de Ingeniería (ACOFI), International Federation of Engineering Education Societies (IFEES)

[65] Kanelopoulos. J, Papanikolaou. J dan Zalimidis. P, 2017, Flipping The Classroom to Increase Students' Engagement and Interaction in a Mechanical Engineering Course on Machine Design, International Journal of Engineering Pedagogy Vol.7, No. 4

[66] Kim. Y, 2015, Learning statics through in-class demonstration, assignment and evaluation, International Journal of Mechanical Engineering Education 0(0) 1-15

[67]Blum. M.M and Dannenhoffer. J.F, 2017, Integrated use of Programming in Machine Design Course, ASEE Paper ID \#18448 c American Society for Engineering Education, 2017

[68] Ćwikła. G, 2013, Interactive 3D Presentation as A Tool in Learning of The Technological Processes Design, Selected Engineering Problems No.4, Institut of Engineering Process Automation and Integrated Manufacturing System

[69] Li. X, Wei. J, Ding. S and Wang. Q, 2017, Teaching Mode of Mechanical Design Course based on Simulation Analysis Technology, iJET - Vol. 12, No. 7, 2017

[70] Suraishkumar. G. K, 2017, Strategies to Improve Learning of All Students in A Class, European Journal of Engineering Education 2017

[71]Green. G and Kennedy. P, 2001, Redefining Engineering Education: The reflective practice of Product Design Engineering, International Journal of Engineering Education 17(1) January 2001

[72] Davies . H.C, 2013, Integrating a Multi-University Design Competition Into a Mechanical Engineering Design Curriculum Using Modern Design Pedagogy, Journal of Engineering Design, 2013, Vol. 24, No. 5, 383-396

[73]Fatmadilla. D, Usmeldi dan Krismadinata, Penerapan Strategi Training Within Industry Dalam Pembelajaran Mengoperasikan Sistem Pengendali Elektromagnetik, Jurnal Inovasi, Vokasional dan Teknologi, Vol. 17 No. 2, Oktober 2017

[74] Anderson. K.J.B, Courter. S.S, McGlamery. T, Kelly. T.M.N and Nicometo. C.C, 2010, 
Understanding Engineering Work and Identity: A Cross-Case Analysis of Engineers Within Six Firms, Engineering Studies Vol. 2, No. 3, December 2010, 153-174

[75]Baronos. A, 2016, Education For SustainabilityExperiences From Greece, IOP Conf. Series: Materials Science and Engineering 161 (2016) 012103 doi:10.1088/1757-899X/161/1/012103

[76] Saha. S. K, 2006, Design for effective Teaching and Learning in Technical Education, National Conference on Design for Product Life, 17-18 Feb 2006

[77] Clark. R.M, Mary. B.S, Dlbudny, Karen M.B, Clark. W.W,Norman. B.A, Parker. R.S, Patzer. J.F and Slaughter. W.S, 2017, Flipping Engineering Courses: A School Wide Initiative, Advances in Engineering Education

[78] Sherry H and Agogino. A.M, 1995, Scaffolding Knowledge Integration through Designing Multimedia Case Studies of Engineering Design, Frontiers in Education Conference 4dl.

[79] Cohen. K and Katz. R, 2015, Teaching Mechanical Design Practice in Academia, Procedia CIRP 36 (2015) $177-181$

\section{Biodata Penulis}

Edi Septe, Dosen Universitas Bung Hatta, lahir di Payakumbuh, 1 September 1963. Sarjana Teknik Mesin Universitas Bung Hatta, 1989 dan Magister Teknik Rekayasa Korosi Institut Teknologi Bandung 1997. Saat ini menjadi Mahasiswa Program Doktor Pendidikan Teknologi dan Kejuruan Universitas Negeri Padang

Nizwardi Jalinus, Dosen Universitas Negeri Padang, lahir di Padang 22 Agustus 1952. Beliau Guru Besar bidang kurikulum Pendidikan teknologi kejuruan di Jurusan teknik mesin. 
